Research Article

www.ijrap.net

\title{
EFFECT OF THE AQUEOUS EXTRACT OF BARK OF ALSTONIA SCHLOLARIS LINN. ON RESPIRATORY BURST IN POLYMORPHONUCLEAR NEUTROPHILS (PMNs) \\ Dalvi Alok Atmaram ${ }^{1}$, Bhalerao Supriya Sudhakar ${ }^{2}$, Munshi Renuka Premal ${ }^{2}$ ${ }^{1}$ DY Patil College of Biotechnology, Navi Mumbai, Maharashtra, India \\ ${ }^{2}$ Dept. of Clinical Pharmacology, TNMC \& BYL Nair Ch. Hospital, Mumbai, Maharashtra, India
}

Received on: 02/05/12 Revised on: 30/06/12 Accepted on: 10/08/12

\author{
*Corresponding author \\ Central, Mumbai 400008 Maharashtra, India Email: supriya.bhalerao@gmail.com \\ DOI: $10.7897 / 2277-4343.03529$ \\ Published by Moksha Publishing House. Website www.mokshaph.com \\ All rights reserved.
}

Dr. Supriya Bhalerao, Sr. Research Officer, Dept. of Clinical Pharmacology, TN Medical College \& BYL Nair Hospital, Dr. AL Nair Road, Mumbai

\section{ABSTRACT}

In the present study we explored the effect of aqueous extract of Alstonia scholaris bark as compared to known stimulant PMA (Phorbol 12-myristate 13-acetate), on the respiratory burst in Polymorphonuclear Neutrophils (PMNs). The formation of the various Reactive Oxygen Species (ROS) were measured by performing three in vitro assays viz. Nitro blue Tetrazolium (NBT) assay, Nitrite estimation and Chemiluminescence assay. The studied concentrations of Alstonia scholaris were $(1,5,10$ and $25 \mathrm{mg} / \mathrm{ml})$ to evaluate efficacy. We observed an increase in the respiratory burst at all the studied concentrations in all the assays indicating its immunomodulatory effect. In case of superoxide radical generation and formation of ROS, we observed maximum increase with the lowest and highest concentrations ( 1 and $25 \mathrm{mg} / \mathrm{ml}$ respectively) as compared to two intermediate concentrations $(5$ and $10 \mathrm{mg} / \mathrm{ml}$ ). While in case of nitrite formation, a concentration dependant increase was seen with maximum response at 25 $\mathrm{mg} / \mathrm{ml}$. These results were however not significant statistically as compared to either cell control or the standard drug, PMA. Our findings thus support the folklore use of the aqueous extract of Alstonia scholaris bark as immunomodulatory agent.

Key words: Alstonia scholaris, Chemiluminescence assay, Nitrite estimation, Nitro blue Tetrazolium assay.

\section{INTRODUCTION}

Alstonia scholaris Linn. R.Br. (family Apocynaceae) is widely found in India in sub Himalayan region. ${ }^{1}$ It also has wide occurrence in the Asia-Pacific region to northern Australia. Traditionally various parts of this plant are used to treat variety of diseases. The bark is used as thermogenic, digestive, laxative, anthelmintic, febrifuge, antipyretic, depurative, galactogogue, stomachic, cardiac and general tonic. It is useful in malarial fever, abdominal disorders, diarrhea, dysentery, dyspepsia, leprosy, skin diseases, pruritus, tumors, chronic and foul ulcers, asthma, bronchitis, cardiopathy, helminthiasis, agalactia and debility. The milky exudates are described to be useful in ulcers, otalgia and rheumatic pain. ${ }^{2}$

In recent days, this plant has invited the attention of researchers worldwide for its pharmacological activities. Evidence for its anti-microbial ${ }^{3}$, anti-malarial ${ }^{4}$, antidiarrhoeal $^{5}$, anti-mutagenic ${ }^{6}$, and wound healing ${ }^{7}$ and anti-cancer ${ }^{8}$ activities has been documented till date. The bark extract of Alstonia scholaris has been reported to have an immunostimulant effect. The aqueous extract at low dose induced the cellular immune response while at high dose inhibited the delayed type of hypersensitivity reaction ${ }^{9}$.

Interestingly, in the Southern Part of India, particularly Kerala, there is a belief that if a drop of extract obtained from the bark of this plant is consumed during the month of Ashadha (as per Hindu calendar), it provides immunity against all diseases. To verify this claim, in the present project we studied the effect of the aqueous extract of the Alstonia bark on the respiratory burst in Polymorphonuclear Neutrophils (PMNs).
'Respiratory burst' is a metabolic process that occurs in activated PMNs during phagocytosis. ${ }^{10}$ This process results in the activation of a membrane bound oxidase that catalyzes the reduction of oxygen to superoxide anion, a reactive oxygen intermediate that is extremely toxic to ingested micro-organisms. This superoxide anion also generates other powerful oxidizing agents, including hydroxyl radicals and hydrogen peroxide, which help in the body's first line of defense against microorganisms. In the present study, we measured the formation of the various Reactive Oxygen Species (ROS) by performing three in vitro assays viz. Nitro blue Tetrazolium (NBT) assay $^{11}$, Nitrite estimation ${ }^{12}$ and Chemiluminescence $\operatorname{assay}^{13}$.

\section{MATERIAL AND METHODS \\ Drugs}

The aqueous extract of Alstonia scholaris (extractive value not less than 10\%) was procured from M/s Atharva Ayurved Pharmaceuticals, Nasik (Batch No. 906085, Mfg. date $7^{\text {th }}$ June 2009). As per the WHO guidelines, physico-chemical tests viz., total ash, acid insoluble ash, moisture content, water and alcohol extractive values, $\mathrm{pH}$ and microbial load were carried out prior to the conduct of the experiments to test the activity of the extract.

Phorbol 12-myristate 13-acetate commonly referred to as PMA (Sigma-Aldrich) was used as standard drug at a working concentration of $10^{-6} \mathrm{M}$.

\section{Sample preparation}

The plant extract was dissolved in distilled water to prepare a stock solution of $100 \mathrm{mg} / \mathrm{ml}$. From this stock solution, further dilutions were made. 


\section{Chemicals}

Ficoll hypaque (HiMedia) was used while isolating the PMNs. Minimum Essential Media (MEM) (HiMedia) and Roswell Park Memorial Institute medium (RPMI 1640) (Gibco) were used for PMN culture in the various assays. Nitro blue Tetrazolium referred to as NBT (SigmaAldrich), the working solution $(10 \mathrm{mg} / \mathrm{ml})$ of which was prepared in distilled water and stored in amber colored vial. This was further diluted 1:1 using MEM for actual assay. Griess reagent (Sigma-Aldrich) was diluted in nitrite free distilled water prior to use $(1 \mathrm{mg} / 2.5 \mathrm{ml}$ in deionized water). Luminol (Sigma-Aldrich) was prepared in distilled water to prepare a stock concentration of $10 \mathrm{mg} / \mathrm{ml}$ in \& stored in an amber colored vial. This was further diluted 1:1 using MEM for actual assay.

\section{Procedures}

As this study involved using human blood samples, Institutional Ethics Committee permission was obtained prior to initiation of the study and written Informed Consent was taken from every participant before recruiting him/her into the study.

In order to evaluate the effect of the plant extract on respiratory burst in PMNs, isolated cells from the blood of 6 normal and healthy volunteers (age group of 18 to 30 years) were used. Volunteers with smoking habits, history of any psychological disorder, suffering from any major illness, history of receiving treatment for any condition during 4 weeks prior to enrolment and who had participated in any other investigational study in last 4 weeks were excluded from the study.

Once recruited, $10 \mathrm{ml}$ blood was aseptically collected from the ante-cubital vein of each volunteer into a glass tube containing EDTA. $2 \mathrm{ml}$ of blood was transferred to a suspension tube for plasma separation while $8 \mathrm{ml}$ blood was diluted using saline in the proportion (1:1). This diluted blood was gently overlaid on $2 \mathrm{ml}$ of Histopaque in graduated centrifuge tube. The tubes were centrifuged at $1500 \mathrm{rpm}$ for 30mins. After centrifugation, the upper layers of plasma, Histopaque and that of monocyte were discarded using a micropipette. $1 \mathrm{ml}$ of PMN-RBC layer was added to a tube containing Dextran + plasma; mixed gently and incubated at $37^{\circ} \mathrm{C}$ for $1 \mathrm{hr}$. The supernatant containing PMN was then collected in a new tube.

A viability test using the Trypan Blue dye exclusion method $^{14}$ was carried out prior to conducting the assays to measure respiratory burst in order to exclude those concentrations of the plant extract affecting neutrophil viability. PMNs were incubated for 1 hour along with different concentrations of the test drug (concentrations ranging from 1to $100 \mathrm{mg} / \mathrm{ml}$ ). All sets were run in duplicates. Only those concentrations of the plant extract showing a viability of $90 \%$ and more were selected for the actual assay.

\section{Assays to measure respiratory burst}

\section{Nitro blue Tetrazolium (NBT) Assay ${ }^{11}$}

This is a semi-quantitative microscopic Nitro blue Tetrazolium (NBT) assay to determine the production of superoxide anion $\left(\mathrm{O}_{2}^{-}\right)$

For all these assays, the count of PMNs was adjusted to $1 \times 10^{6}$ cells using the medium, either MEM (in case of NBT and Chemiluminescence assays) or RPMI (for NO estimation assay). $100 \mu \mathrm{l}$ of the adjusted cells were deposited in the 96 well ELISA plate. The plate was incubated for 30 minutes in humid conditions for the adherence of the PMN's to the bottom of the well. The adherence of the PMNs was observed under an inverted microscope. The supernatant was discarded and replaced by fresh MEM. PMA and test drugs were added to the standard control and test drug wells respectively. Wells containing only PMNs served as cell control wells. $50 \mu \mathrm{l}$ working solution of NBT was added (stock: $10 \mathrm{mg} / \mathrm{ml}$ ) to the wells and the plate was incubated for 2 hours in the laminar air flow unit in the dark conditions since NBT is sensitive to light. The supernatant was then removed and the cells were fixed with absolute methanol. The cells were washed twice with $70 \%$ methanol and air dried. The formazan crystals obtained by the reaction were then dissolved in 2M Potassium hydroxide and Di methyl sulfoxide (DMSO). The contents of all the wells were mixed uniformly and the plate was read at $620 \mathrm{~nm}$ in the ELISA reader.

\section{Nitrite Estimation assay}

This is a method for indirect determination of nitric oxide $\left(\mathrm{NO}^{-}\right)$involving the spectrophotometric measurement of its stable decomposition products; nitrates and nitrites.

$100 \mu \mathrm{l}$ of the adjusted cells were deposited in the 96 well ELISA plate. The plate was incubated for 30 minutes in humid conditions for the adherence of the PMNs to the bottom of the well. The adherence of the PMNs was observed under an inverted microscope. The supernatant was discarded and replaced by fresh medium. Test drug was added to the wells excluding cell control and standard control wells. The plate was then incubated for 1 hour in incubator at $37^{\circ} \mathrm{C}$. After 1 hour, $2 \mu \mathrm{l}$ PMA and $100 \mu \mathrm{l}$ Griess reagent was added to the wells (except cell control wells). The plate was then immediately read at $550 \mathrm{~nm}$ on an Elisa reader. The concentration of nitrite was then obtained using a pre-plotted standard curve with 5-100 $\mu \mathrm{M}$ concentrations of Sodium nitrite $\left(\mathrm{NaNO}_{2}\right)^{12}$.

\section{Chemiluminescence assay}

This is a method to measure the production of ROS (like $\mathrm{O}_{2}^{-}$and $\mathrm{H}_{2} \mathrm{O}_{2}$ ) using luminol amplified chemiluminescence. $230 \mu \mathrm{l}$ adjusted PMNs were seeded in 96 well plates. $2.5 \mu \mathrm{l}$ of Test drug was added to the wells (except cell control and standard control wells) and volume in the wells was adjusted to $240 \mu \mathrm{l}$ using MEM. Wells containing only PMNs served as Cell control. 10 $\mu 1$ luminol dye was added to all wells. PMA was also added to all wells except the cell control wells. The plate was kept for 1 hour in incubator at $37^{\circ} \mathrm{C}$, after which it was loaded on the luminescence counter. The baseline readings $(\mathrm{X})$ were documented. After this, 3 readings were taken after 2 minutes (time required for initiation of PMA activity ${ }^{15}$ ), after 5 minutes (activity period for luminol $^{16}$ ) and the last reading was taken after 80 minutes of exposure (activity period of PMA as observed in our earlier work: data unpublished). These were considered as $\mathrm{Y} 1, \mathrm{Y} 2$ and $\mathrm{Y} 3$ respectively and the basal readings (X) were subtracted from each of these to get the activity at that time point ${ }^{13}$.

\section{Statistical analysis}

The results are expressed as Mean $\pm \mathrm{SD}$. The results were analyzed using One-way ANOVA followed by Turkey's 
Post-hoc test. The level of significance was considered as $\mathrm{p}<0.05$.

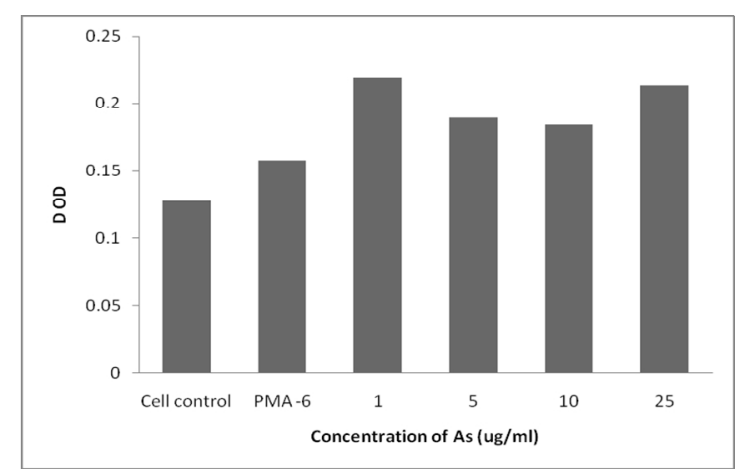

Figure 1: Effect of Alstonia scholaris on superoxide radical generation

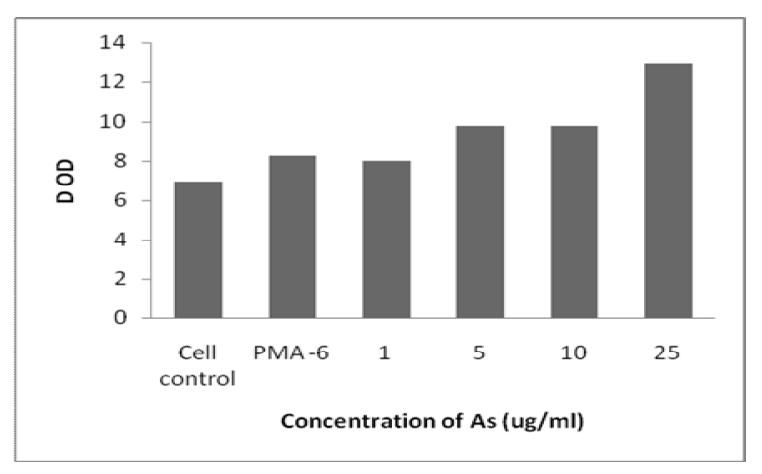

Figure 2: Effect of Alstonia scholaris on nitrite formation

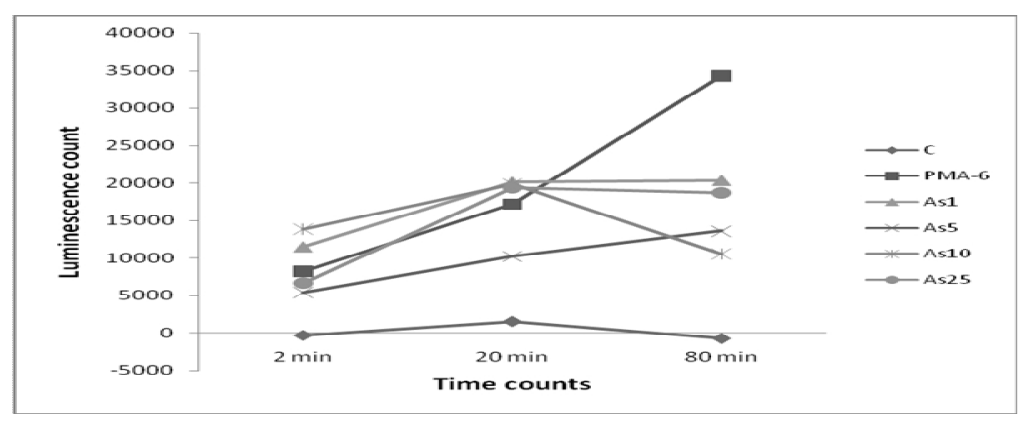

Figure 3: Effect of Alstonia scholaris on formation of Reactive Oxygen Species

\section{RESULTS}

As compared to the control cells, the viability was found to be significantly affected only at the highest concentration i.e. $100 \mathrm{mg} / \mathrm{ml}$. Although the viability was not affected at 50 and $75 \mathrm{mg} / \mathrm{ml}$ concentrations, we used the lower concentrations $(1,5,10$ and $25 \mathrm{mg} / \mathrm{ml})$ to evaluate efficacy.

Effect of Alstonia scholaris on superoxide radical generation

Although all the studied concentrations of Alstonia scholaris aqueous extract showed increase in the superoxide radical generation, maximum increase was seen with the lowest $(1 \mathrm{mg} / \mathrm{ml})$ and the highest $(25$ $\mathrm{mg} / \mathrm{ml}$ ) concentrations. This increase was however not significant statistically. The results obtained are shown in Figure 1.

\section{Effect of Alstonia scholaris on nitrite formation}

Alstonia scholaris exhibited a concentration dependant increase in the nitrite formation, although not statistically significant. The results are shown in Figure 1.

Effect of Alstonia scholaris on formation of Reactive Oxygen Species (ROS)

Similar to superoxide radical generation, all concentrations of Alstonia scholaris showed an increase in the formation of ROS revealed by increase in the luminescence count, the concentrations $1 \mathrm{mg} / \mathrm{ml}$ and 25 $\mathrm{mg} / \mathrm{ml}$ showed maximum increase. This increase was again not significant statistically. The results have been summarized in Figure 3.

\section{DISCUSSION}

Respiratory or oxidative burst is an important phenomenon in the process of phagocytosis. During phagocytosis of microbial intruders, phagocytes of the innate immune system increase their oxygen consumption through the activity of an NADPH-oxidase that generates superoxide anion $\left(\mathrm{O}_{2}^{-}\right)$and hydrogen peroxide $\left(\mathrm{H}_{2} \mathrm{O}_{2}\right)$. These oxygen metabolites give rise to yet other reactive oxygen species that are strongly anti-microbial and inducing apoptosis in other immune reactive cells. The plant, Alstonia scholaris is reported to have immunomodulatory activity. ${ }^{9}$ A comparative study of aqueous and ethanol extracts carried out in BALB/c mice showed that at the same doses $(50,100$ and $200 \mathrm{mg} / \mathrm{kg}$ b.w.) the aqueous extract had higher phagocytic index (1.39-1.79) than the ethanol extracts (0.81-0.93) in normal mice. Hence, as a further step in the present study, we evaluated the effect of aqueous extract of the plant bark on respiratory burst in PMNs using 3 in vitro assays. We used a range of concentrations viz. $1-25 \mu \mathrm{g} / \mathrm{ml}$ of the plant extract and observed an increase in the respiratory burst at all the studied concentrations in all the assays indicating its immunomodulatory effect. Our findings thus support the folklore use of the plant for strengthening immunity. In case of superoxide radical generation and formation of ROS, we observed maximum increase with the lowest and highest concentrations ( 1 and $25 \mathrm{mg} / \mathrm{ml}$ respectively) as compared to two inter mediate concentrations ( 5 and $10 \mathrm{mg} / \mathrm{ml})$. While in case of nitrite formation, a concentration dependant increase was seen with maximum response at $25 \mathrm{mg} / \mathrm{ml}$. These results were 


\section{Bhalerao Supriya Sudhakar et al / IJRAP 3(5), Sep - Oct 2012}

however not significant statistically as compared to either cell control or the standard drug, PMA. A probable reason could be because the assays were carried out using PMNs isolated from blood samples of different individuals. The intra-individual differences in the response of PMNs to PMA have been well documented. ${ }^{11}$ In addition; small sample size and the crude nature of the extract used might have led to high standard deviation ultimately affecting the statistical significance. Further studies with a bigger sample size and homogenous cell population-by employing cell lines like U937 (myeloid lineage) and THP1 (Human acute monocyte leukemia cell line) would provide a better idea about the efficacy of the test drug. Alstonia scholaris contains alkaloids as major phytoconstituents. ${ }^{17}$ There are reports on inhibitory action of Flavanoids on respiratory burst in neutrophils. ${ }^{18}$ However, any such association between alkaloids and respiratory burst has not yet been reported. It will be further interesting to isolate the various alkaloids present in the plant and study their effect on respiratory burst in PMNs.

\section{ACKNOWLEDGEMENT}

We acknowledge Dr. Vinayak from Atharva Ayurved Pharmaceuticals for providing the plant extract.

\section{REFERENCES}

1. Nadkarni AK, Nadkarni KM. Indian Materia Medica, Vol. I. Bombay: Popular Prakashan; 1976.

2. Kirtikar KR, Basu BD. Indian Medicinal Plants, Vol. II. Bishen Singh Mahendrapal Singh, 23A, New Connaught Place, Dehradun:1998, p. 1565

3. Versha P, Ghosh B, Anroop B, Ramanjit M. Antimicrobial activity of Alstonia scholaris leaf extracts. Indian drugs 2003; 40(7): 412 413

4. Gandhi M, Vinayak VK. Preliminary evaluation of extracts of Alstonia scholaris bark for in vivo antimalarial activity in mice. J. Ethnopharmacol $1990 ; \quad 29(1): \quad 51-\quad 57$ http://dx.doi.org/10.1016/0378-8741(90)90097-D

5. Patil RS, Juvekar AR, Joglekar SN et al. Study of anti-diarrhoeal activity of Alstonia scholaris bark. Indian Drugs 1999; 36(7): $463-$ 465

6. Lim-Sylianco CY, Jocano AP, Linn CM. Anti-mutagenicity of twenty Philippine plants using the micronucleus test in mice. Philippine Journal of Science 1990; 117(3): 231-235

7. Arulmozhi SL, Rasal VP, Sathiyanarayanan L, Ashok P. Screening of Alstonia scholaris Linn. R. Br., for wound healing activity.
Oriental Pharmacy and Experimental Medicine 2007b; 7(3): 254260. http://dx.doi.org/10.3742/OPEM.2007.7.3.254

8. Keawpradub N, Houghton PJ, Eno-Amooquaye E, Burke PJ Activity of extracts and alkaloids of thai Alstonia species against human lung cancer cell lines. Planta Med 1997; 63(2): 97-101 http://dx.doi.org/10.1055/s-2006-957621

9. Iwo MI, Soemardji AA, Retnoningrum DS, Sukrasno UUM. Immunostimulating effect of pule (Alstonia scholaris L. R.Br., Apocynaceae) bark extracts. Clin Hemorheol Microcirc, 2000; 23, 177-183 PMid: 11321438

10. Clark RA. Activation of the neutrophil respiratory burst oxidase. J Infect Dis 1999; 179 (Supplement 2):S309-S317. http://dx.doi.org/10.1086/513849 PMid:10081501

11. Munoz M, Cedeno R, Rodriguez J, Van der Knaap WPW, Mialhe E, Bachère $\mathrm{E}$. Measurement of reactive oxygen intermediate production in haemocytes of the penaeid shrimp, Penaeus vannamei. Aquaculture 2000; 191: 89-107 http://dx.doi.org/10.1016/S00448486(00)00420-8

12. Jun CD, Choi BM, Hoon-Ryu Um J Y et al Synergistic Cooperation between Phorbol Ester and IFN-y for Induction of Nitric Oxide Synthesis in Murine Peritoneal Macrophages. J. Immunol. 1994; 153, 3684-3690 PMid:7523501

13. Van Epps DE, Goodwin J, Murphy S Age-Dependent Variations in Polymorphonuclear Leukocyte Chemiluminescence. Infection and Immunity 1978; 22(1): 57-61 PMid:730350 PMCid:422115

14. Tolani S. A method for viable cell count. Tissue Cult Assoc Manual 1975; 1: 37-38 http://dx.doi.org/10.1007/BF00914435

15. Beall GD, Repine JE, Hoidal JR, Rasp FL Chemiluminescence by human Alveolar Macrophages: Stimulation with Heat-Killed Bacteria or Phorbol Myristate Acetate. Infect. Immun. 1977; 17(11): 117-120 PMid:885610 PMCid:421090

16. Lieberman $M$ Determination of neutrophil activation by chemiluminescence using the Packard TopCountTM Microplate scintillation and luminescence counter. Topcount Topics available at http://www.perkinelmer.com/CMSResources/Images $\quad / 44$ 73158APP TopCountNeutrophilActChemilumin.pdf accessed on 7th December 2011

17. Abhijit Dey Alstonia scholaris R.Br. (Apocynaceae): Phytochemistry and pharmacology: A concise review. Journal of Applied Pharmaceutical Science 01 (06); 2011: 51-57

18. Milan C, Petko D, Maria K, Ondrej V, Gabriela A, Antonin L. Flavonoids inhibit the respiratory burst of neutrophils in mammals available at http://downloads.Mts.Hindawi.com/ MTSfiles/OXIMED/papers/ DPECB/181295.v1. pdf last accessed on 9th April 2012

\section{Cite this article as:}

Dalvi Alok Atmaram, Bhalerao Supriya Sudhakar, Munshi Renuka Premal. Effect of the Aqueous extract of bark of Alstonia sclolaris Linn. on respiratory burst in Polymorphonuclear neutrophils (PMNs). Int. J. Res. Ayur. Pharm. 2012; 3(5):720-723 